Journal of Economics, Finance and Accounting Studies (JEFAS)

ISSN: 2709-0809

DOI: 10.32996/jefas

Journal Homepage: www.al-kindipublisher.com/index.php/jefas

\title{
Analysis of Capital Adequacy Ratio (CAR), Non-Performing Loan (NPL), and Net Interest Margin (NIM) in Predicting Financial Distress in Financial Reports of PT. Bank Rakyat Indonesia (Persero) Tbk
}

\author{
Julie Abdullah ${ }^{1}$ (D) Wahyudin Hasan² 8 (D), and Sri Yulan Dusa ${ }^{3}$ (D) \\ ${ }^{123}$ Department of Accountancy, Faculty of Economy, Universitas Gorontalo, Gorontalo, Indonesia \\ $\triangle$ Corresponding Author: Julie Abdullah, E-mail: julieabdullah123@gmail.com
}

\section{ARTICLE INFORMATION ABSTRACT}

Received: August 09, 2020

Accepted: October 01, 2021

Volume: 3

Issue: 2

DOI: $10.32996 /$ jefas.2021.3.2.9

\section{KEYWORDS}

CAR, NPL, NIM, Financial Distress
The present work investigates and predicts the condition of financial distress in PT Bank Rakyat Indonesia (persero) Tbk, Unit Wonosari. All data, comprising quantitative and qualitative data, were analyzed based on the financial ratio. These data were retrieved from observation and direct interviews. Based on the data analysis, the hypothesis stating that PT Bank Rakyat Indonesia (persero) Tbk Unit Wonosari did not experience financial distress was accepted. This is because the results of the measurement of CAR, NPL, and NIM of the bank are in good condition (CAR and NIM fell under a very good category, and NPL fell under the good category). It can be concluded that PT Bank Rakyat Indonesia (persero) Tbk Unit Wonosari did not experience financial problems.

\section{Introduction}

An economic system is integral to the progress of a nation. For this reason, it is safe to say that the economic system determines the prosperity of the people in the country. It is also worth noting that a poor economic system has led to the bankruptcy of companies, which begins with financial distress.

The emergence of many bankruptcy prediction models remarks the anticipative measures and early warning systems of financial distress. Further, the models can serve as the media to identify everything required to improve the condition to mitigate bankruptcy. Such a condition encourages any early warning measures to prevent more complex problems regarding economic conditions. The early detection of bankruptcy enables companies, investors, creditors (financial institutions), and government to prepare any measurement to prevent financial crisis.

Previous studies have found that CAR (capital adequacy ratio) negatively influenced financial distress, and the hypothesis was refuted; NPL (non-performing loan) positively influenced financial distress in banking companies, and the hypothesis was accepted; NIM (net interest margin) positively affected financial distress in banking companies and the hypothesis was rejected; ROE (return on equity) negatively influenced financial distress and the hypothesis was accepted; BOPO (Operating Expense to Operating Income) positively influenced financial distress in banking companies and the hypothesis was refuted; LDR (loan to deposit ratio) positively contributed to financial distress in banking companies and the hypothesis was rejected (Rahmania and Hermanto, 2014).

Similar to the previous studies, the present work relied on performance ratio or banking ratio, ranging from capital adequacy ratio (CAR), non-performing loan (NPL), to net interest margin (NIM) to check the financial health of the bank. Capital adequacy ratio (henceforth, CAR) refers to the measures of banks' capital to cover the current and upcoming risks. Another indicator in checking the bank's health is a non-performing loan or NPL. Business risk is often referred to as the quality of earning assets. Riyadi (2006) describes credit risks as potential risks where a bank borrower is unable to pay the debt and the interest. The quality of credit is determined by its collectability, i.e., credit quality is determined by its collectability, interest payments, and loan principal, as well as the ability of the debtor (the state of the debtor's business). The standard ratio of NPL allowed by Bank Indonesia is $5 \%$ at maximum. If the NPL exceeds $5 \%$, the companies' finances are not in good condition.

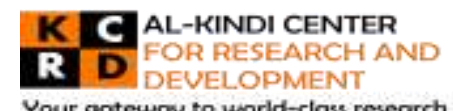

Your goteway to world-class research

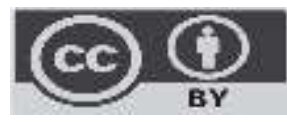

Published by Al-Kindi Center for Research and Development. Copyright (c) the author(s). This open access article is distributed under a Creative Commons Attribution (CC-BY) 4.0 license 
Other indicators include NIM, which is applied to examine the capability of earning assets on net interest income or NII (Sawir as cited in Suharman, 2007). Earning assets consist of securities, futures, loans, investments, and foreign exchange assets. NIM is the ratio of net interest income to the average earning assets; it is derived from interest income minus interest expense. Earning assets that are taken into account are interest-bearing assets (Prasnugraha, 2007).

The above discussion underpins the rationale to investigate the roles of financial banking ratios in predicting the financial condition of banking institutions through a paper entitled "Analysis of Capital Adequacy Ratio, Non-performing Loan, and Net Interest Margin in Predicting Financial Distress in Financial Reports of PT Bank Rakyat Indonesia (persero) Tbk."

\section{Literature Review}

\subsection{Financial Performance}

Fahmi (2011) defines financial performance as a measurement that determines how a firm can use its assets and implement all financial regulations accordingly. The company's financial performance can be examined using financial ratios stated in the company's financial reports. A financial ratio is a relative magnitude in the form of numbers stated in financial reports that show the performance of the company, such as its management and attainment in a specific period. The ratio also functions to assess the way the company utilizes its resources effectively and efficiently. All information in the financial ratio can be used as a reflection of the company to improve every aspect they require to meet its target.

\subsection{Financial Ratio}

According to Usman (2003), an analysis of financial performance aims to identify the financial development and position of a company. This type of analysis is based on the company's financial reports and other economic data of the company (stated in the annual report).

Winarto (2006) argues that financial distress can be predicted by examining the financial ratios in the financial performance reports. A financial ratio analysis is of paramount importance to the internal of the company's management to track its financial achievement, enabling the company to establish the planning. The analysis is also essential for creditors and investors to determine credit grant policies and investments.

Financial ratio analysis shows the relationship between selected items from financial report data. The ratio provides information regarding mathematical relationships from one quantity to another.

\subsection{Financial Distress}

Almilia (2006) describes financial distress as a financial phase before bankruptcy or liquidity. Endri (2009) further adds that financial distress refers to a condition in a company that experiences negative net profits for several years. In that situation, the company's operating cash flow is insufficient to cover the company's obligations, such as a letter of credit (L/C) or interest cost. As a result, the company is forced to take corrective actions. Financial distress can lead a company to experience default in its contract, thus forcing the firm to restructure its financial system. Creditors and investors of the firm.

Financial distress also leaves the company in a state where it cannot fulfill other obligations, such as credit trading or interest spending.

\subsection{Predicting Financial Distress}

Financial distress is a sign of bankruptcy. If bankruptcy is a failure of a company in carrying out its operational activities in order to generate company profitability for the sustainability of the company, financial distress is a situation in which a stage of decline occurs in the company's financial condition. This usually occurs before bankruptcy or liquidity. Simply put, financial distress is a signal and an early warning for a company to go bankrupt if it is not immediately addressed.

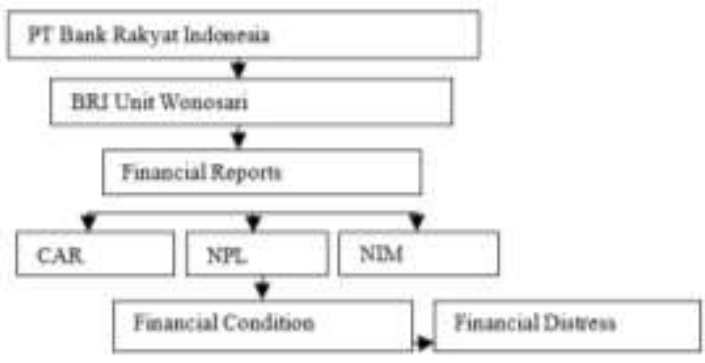

Figure 1. Conceptual Framework 
The present work focused on analyzing the financial performance to predict the financial condition of PT Bank Rakyat Indonesia (persero) Tbk of BRI Unit Wonosari. All data regarding the bank were limited to the data from 2010 to 2019 . This research was conducted for two months, starting from the approval of the research proposal.

\subsection{Research Variables}

Variables of the present study consisted of independent variables (financial performance, encompassing CAR, NPL, and NIM) and dependent variables (financial distress).

\subsection{Data Collection}

In the present study, the data were collected using two methods, as follows. (1) Library research: literature, such as books, magazines, and other publications related to the problems of this study were collected and examined. (2) Field study: this method comprised three steps, namely observation, and recording of the research variables, interview with stakeholders, and documentation.

\subsection{Types and Sources of Data}

The types of data comprised of two types. They are (1) Quantitative data, i.e., numerical data retrieved from financial reports from 2010 to 2019. and (2) Qualitative data, i.e., data in the form of descriptive information that discusses financial performance factors and their significance to predict the financial distress of PT. Bank Rakyat Indonesia (persero) Tbk in BRI unit Wonosari and other information related to the research problem.

For sources of Data, the primary data was taken from interviews and observation; while, the secondary data were retrieved from previous studies or documents from relevant institutions.

\subsection{Analysis Method}

All data of this research were analyzed quantitatively and qualitatively. The analysis relied on ratio analysis methods as discussed below.

\subsubsection{Capital Adequacy Ratio (CAR)}

CAR is a ratio that describes that the bank has enough capital in dealing with specific risks (bank's capitals with risks involved credit, participation, securities, other bank bills). The formula of CAR is displayed below.

$$
\text { CAR }=\frac{\text { Capital }}{\text { Risk }- \text { weighted assets }} \times 100 \%
$$

The detail is presented in the following table.

Table 1. CAR Assessment Criteria

\begin{tabular}{ll}
\hline Ratio & Predicate \\
\hline CAR $\geq 12 \%$ & Very good \\
$9 \% \leq$ CAR $\leq 12 \%$ & Good \\
$8 \% \leq$ CAR $\leq 9 \%$ & Fair \\
$6 \% \leq$ CAR $\leq 8 \%$ & Poor \\
CAR $\leq 6 \%$ & Very poor \\
\hline
\end{tabular}

Source: Bank Indonesia

\subsubsection{Non-Performing Loan (NPL)}

According to Almilia and Heriningtyas (2005), the NPL ratio shows the bank's managerial capacity in managing bad credits. Such credits refer to the ones given to third parties, excluding credits to other banks. The higher the NPL, the worse the bank credit quality, resulting in an increase in bad credits. Therefore, the bank will be more likely to experience greater financial distress. Provided below is the formula of NPL

$$
\text { NPL }=\quad \frac{\text { Bad Credits }}{\text { Total Credits }} \times 100 \%
$$

Criteria of NPL ratios are displayed in the following table.

Table 2. NPL Assessment Criteria

Ratio Predicate




\begin{tabular}{ll}
\hline$N P L$ Ratio $\leq 2 \%$ & Very good \\
$2 \% \leq N P L \leq 3 \%$ & Good \\
$3 \% \leq N P L \leq 6 \%$ & Fair \\
$6 \% \leq N P L \leq 9 \%$ & Poor \\
$N P L \geq 9 \%$ & Very poor \\
\hline
\end{tabular}

Source: Bank Indonesia

\subsubsection{Net Interest Margin (NIM)}

NIM is a ratio used to measure the company's managerial capacity to manage its earning assets to generate net interest income. NIM calculation is from the comparison between net interest income and earning assets. Net interest income is obtained from interest income subtracted by interest charge and annualized net interest income. Earning assets calculated are earning assets that earn interest. Provided below is the formula of NIM.

$$
\mathbf{N I M}=\frac{\text { Net Interest Income }}{\text { Earning Assets }} \times 100 \%
$$

Criteria of NIM is provided in the following table.

Table 3. NIM Assessment Criteria

\begin{tabular}{ll}
\hline Ratio & Predicate \\
\hline $\mathrm{NIM} \geq 2 \%$ & Very good \\
$2 \% \leq \mathrm{NIM} \leq 1.2 \%$ & Good \\
$1.2 \% \leq \mathrm{NIM} \leq 1.0 \%$ & Fair \\
$1.0 \% \leq \mathrm{NIM} \leq 0.75 \%$ & Poor \\
$\mathrm{NIM} \leq 0.75 \%$ & Very poor \\
\hline
\end{tabular}

Source: Bank Indonesia

\section{Results and Discussion}

\subsection{Results}

\subsubsection{Description of Research Object}

\subsubsection{General Overview of PT. Bank BRI Unit Wonosari}

PT. Bank Rakyat Indonesia (Persero) is the first government bank in Indonesia. In its development, BRI has undergone several names and status changes, which are closely related to the history of the struggle of the Indonesian people. The changes, without doubt, have an essential meaning for the development and growth of BRI. This notion is in line with the vision and mission of BRI in providing services to its users. In its operation, Bank Rakyat Indonesia (Persero) Tbk Unit Wonosari is backed up by professional employees who are determined to perform their tasks accordingly based on the organizational structures. The general overview of the company is elaborated on below.

\subsubsection{BRI Unit Wonosari}

BRI Unit Wonosari is one of the 15 units spread across the Limboto branch. The bank is built to help people who are in need of banking services in their area, making it easier for those who want to deposit funds to or borrow funds from the bank.

\subsubsection{Organizational Structures of Bank BRI Unit Wonosari}

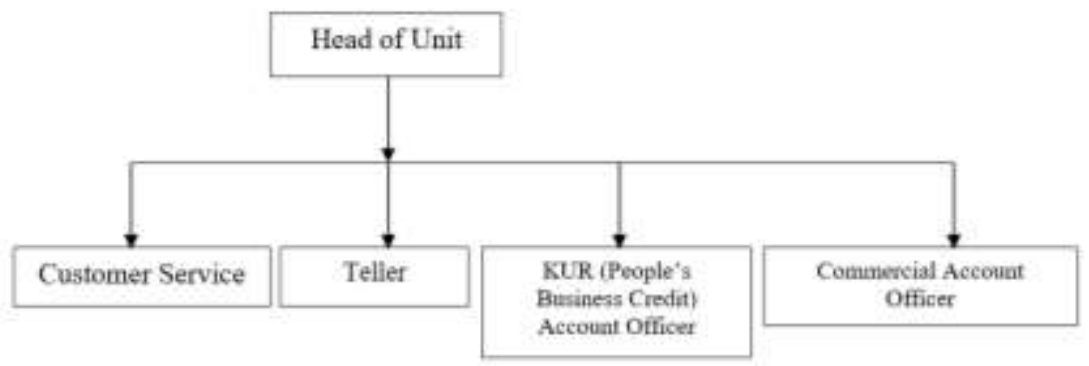

Figure 2. Organizational Structures of Bank BRI Unit Wonosari

\subsubsection{Analysis of Research Results}

\subsubsection{CAR and Financial Distress Prediction}


The formula of calculation of CAR to predict financial distress is as follows.

$$
\mathrm{CAR}=\frac{\text { Capital }}{\text { Risk }- \text { weighted assets }} \times 100 \%
$$

Table 4. Capital and Weighted Assets

\begin{tabular}{lll}
\hline Year & Capital & Weighted Assets \\
\hline 2016 & $1,032,933,000$ & $7,009,182,000$ \\
2017 & $1,112,727,000$ & $9,803,081,000$ \\
2018 & $1,765,133,000$ & $12,180,402,000$ \\
2019 & $1,767,087,000$ & $13,704,726,000$ \\
2020 & $1,865,876,000$ & $14,776,534,000$ \\
\hline
\end{tabular}

Source: Processed Data (2020)

From the data in Table 5.2, the CAR results are as follows.

1. Year of 2016

$\begin{aligned} C A R & =\frac{\text { Capital }}{\text { Risk }- \text { weighted assets }} \times 100 \% \\ C A R & =\frac{1.032 .933000}{7.009 .182000} \times 100 \%=14.74\end{aligned}$

2. Year of 2017

$$
\begin{aligned}
C A R & =\frac{\text { Capital }}{\text { Risk }- \text { weighted assets }} \times 100 \% \\
C A R & =\frac{1.112 .727 .000}{9.803 .081000} \times 100 \%=11.35
\end{aligned}
$$

3. Year of 2018

$$
\begin{aligned}
C A R & =\frac{\text { Capital }}{\text { Risk }- \text { weighted assets }} \times 100 \% \\
C A R & =\frac{1.765 .133000}{12.180 .402000} \times 100 \%=14.49
\end{aligned}
$$

4. Year of 2019

$$
\begin{aligned}
C A R & =\frac{\text { Capital }}{\text { Risk }- \text { weighted assets }} \times 100 \% \\
C A R & =\frac{1.767 .087000}{13.704 .726000} \times 100 \%=12.89
\end{aligned}
$$

5. Year of 2020

$$
\begin{aligned}
C A R & =\frac{\text { Capital }}{\text { Risk - weighted assets }} \times 100 \% \\
\text { CAR } & =\frac{1.865 .876000}{14.776 .534000} \times 100 \%=12,63
\end{aligned}
$$

Table 5. CAR Analysis Results

\begin{tabular}{lll}
\hline Year & CAR & Predicate \\
\hline 2016 & $14.74 \%$ & Very Good \\
2017 & $11.35 \%$ & Good \\
2018 & $14.49 \%$ & Very Good \\
2019 & $12.89 \%$ & Very Good \\
2010 & $12.63 \%$ & Very Good \\
\hline Average CAR & $\mathbf{1 3 . 8 2 \%}$ & Very Good \\
and Predicate & & \\
\hline
\end{tabular}

The above table shows that the CAR level by Bank BRI Unit Wonosari from 2016 to 2020 experiences ups and downs. If based on the Bank Indonesia Standards ( $\geq 12 \%$ ), CAR was in very good health in 2016, yet it fell under good health in 2017. Further, it comes 
back to very good health from 2018 to 2020. In addition, the CAR of Bank BRI Unit Wonosari indicates that the bank has adequate capital to prevent or anticipate risks, especially the risk of bad credits that will lead to the company's financial distress or financial liquidity. With this capital, the bank is able to provide certainty that it will not experience bankruptcy or financial distress in the future.

\subsubsection{NPL Ratio to Financial Distress Prediction}

According to Almilia and Heriningtyas (2005), the NPL ratio shows the bank's managerial capacity in managing bad credits. Such credits refer to the ones given to third parties, excluding credits to other banks. The higher the NPL, the worse the bank credit quality, resulting in an increase in bad credits. Therefore, the bank will be more likely to experience greater financial distress.

NPL $=\frac{\text { Bad Credits }}{\text { Total Credits }} \times 100 \%$

Table 6. Bad credits and Credit Realizations

\begin{tabular}{|l|l|l|}
\hline Year & Bad credits & Total Credit Realizations \\
\hline 2016 & $1,470,745,400$ & $49,353,872,498$ \\
\hline 2017 & $1,879,814,195$ & $68,109,209,958$ \\
\hline 2018 & $2,425,195,752$ & $79,514,614,821$ \\
\hline 2019 & $2,494,142,421$ & $94,118,581,909$ \\
\hline 2020 & $2,889,865,000$ & $100,475,432,143$ \\
\hline
\end{tabular}

Source: Processed Data, 2020

It is presented in table 5.3 that the analysis results of NPL ratio to financial distress prediction of Bank BRI Unit Wonosari are as follows:

1. Year of 2016

$$
\begin{aligned}
\text { NPL } & =\frac{\text { Bad Credits }}{\text { Total Credits }} \times 100 \% \\
\text { NPL } & =\frac{1.470 .745400}{49.353 .872498} \times 100 \%=2.98
\end{aligned}
$$

2. Year of 2017

$$
\begin{aligned}
\text { NPL } & =\frac{\text { Bad Credits }}{\text { Total Credits }} \times 100 \% \\
\text { NPL } & =\frac{1.879 .814195}{68.109 .209 .958} \times 100 \%=2.76
\end{aligned}
$$

3. Year of 2018

$$
\begin{aligned}
\text { NPL } & =\frac{\text { Bad Credits }}{\text { Total Credits }} \times 100 \% \\
\text { NPL } & =\frac{2.425 .195 .752}{79.514 .614821} \times 100 \%=3.05
\end{aligned}
$$

\begin{tabular}{|c|c|c|}
\hline Year & NPL Ratio & Predicate \\
\hline
\end{tabular}

4. Year of 2019

$$
\begin{aligned}
\text { NPL } & =\frac{\text { Bad Credits }}{\text { Total Credits }} \times 100 \% \\
\text { NPL } & =\frac{2.494 .142421}{94.118 .581 .909} \times 100 \%=2.65
\end{aligned}
$$

5. Year of 2020

$$
\begin{aligned}
\text { NPL } & =\frac{\text { Bad Credits }}{\text { Total Credits }} \times 100 \% \\
\text { NPL } & =\frac{2.889 .865000}{100.475 .432 .143} \times 100 \%=2.88
\end{aligned}
$$

Table 7. Predicates of NPL Ratio 


\begin{tabular}{lll}
\hline 2016 & 2.98 & Good \\
2017 & 2.76 & Good \\
2018 & 3.05 & Fair \\
2019 & 2.65 & Good \\
2020 & 2.88 & Good \\
\hline Average NPL Ratio and Predicate & $\mathbf{2 . 8 5}$ & Good \\
\hline
\end{tabular}

Source: Processed Data, 2020

The above table concludes that the NPL ratio of BRI Unit Wonosari in $2016-2017$ and $2019-2020$ ranges from $2 \%$ to $3 \%$ based on the criteria of Bank Indonesia, or in the good predicate. However, in 2018, BRI Unit Wonosari arrived at 3.05\% of bad credits, meaning that the NPL ratio is in the fair predicate based on Bank Indonesia criteria. This signifies that the NPL Ratio in 2016 has declined in the predicate, i.e., fair in 2018, and has increased to the good position of credits with the NPL ratio of $2.65 \%$.

\subsubsection{NIM Ratio to Financial Distress Prediction}

NIM is a ratio used to measure the company's managerial capacity to manage its earning assets to generate net interest income. The calculation of NIM is from the comparison between net interest income and earning assets. Further, NIM is obtained from interest income subtracted by interest charge and annualized net interest income. Earning assets calculated are earning assets that earn interest. The ratio is formulated below:

NIM Ratio $=\frac{\text { Net Interest Income }}{\text { Earning Assets }} \times 100 \%$

Table 8. Net Interest Income and Earning Assets

\begin{tabular}{lll}
\hline Year & Interest Income & Earning Assets \\
\hline 2016 & $220,254,250$ & $10,232,086,000$ \\
2017 & $261,881,250$ & $13,110,787,000$ \\
2018 & $416,966,000$ & $16,694,184,000$ \\
2019 & $622,317,750$ & $19,441,174,000$ \\
2020 & $226,765,000$ & $11,349,056,000$ \\
\hline
\end{tabular}

Source: Processed Data, 2020

It is displayed in table 5.4 that the analysis results of NIM ratio to financial distress prediction of Bank BRI Unit Wonosari are as follows:

1. Year of 2016

$$
\begin{aligned}
\text { NIM Ratio } & =\frac{\text { Net Interest Income }}{\text { Earning Assets }} \times 100 \% \\
\text { NIM Ratio } & =\frac{220.254 .250}{10.232 .086000} \times 100 \%=2.15
\end{aligned}
$$

2. Year of 2017

3. Year of 2018

$$
\begin{aligned}
\text { NIM Ratio } & =\frac{\text { Net Interest Income }}{\text { Earning Assets }} \times 100 \% \\
\text { NIM Ratio } & =\frac{261.881 .250}{13.110 .787 .000} \times 100 \%=2.00
\end{aligned}
$$

$$
\begin{aligned}
\text { NIM Ratio } & =\frac{\text { Net Interest Income }}{\text { Earning Assets }} \times 100 \% \\
\text { NIM Ratio } & =\frac{416.966 .000}{16.694 .184000} \times 100 \%=2.49
\end{aligned}
$$

4. Year of 2019

$$
\begin{aligned}
\text { NIM Ratio } & =\frac{\text { Net Interest Income }}{\text { Earning Assets }} \times 100 \% \\
\text { NIM Ratio } & =\frac{622.317 .750}{19.441 .174000} \times 100 \%=3.20
\end{aligned}
$$

5. Year of $\mathbf{2 0 2 0}$ 


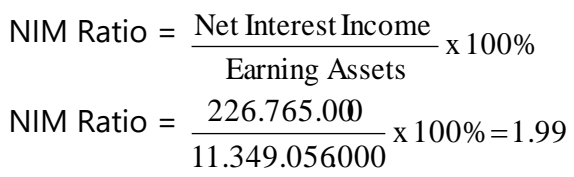

Table 9. Predicates of NIM Ratio

\begin{tabular}{lll}
\hline Year & NIM Ratio & Predicate \\
\hline 2016 & 2.15 & Very Good \\
2017 & 2.00 & Good \\
2018 & 2.49 & Very Good \\
2019 & 3.20 & Very Good \\
2020 & 1.99 & Good \\
\hline Average NIM Ratio and Predicate & $\mathbf{2 . 3 6}$ & Very Good \\
\hline
\end{tabular}

Source: Processed Data, 2020

The earlier calculation shows that Bank BRI Unit Wonosari has a good quality of assets in 2016 - 2019. This is indicated by the bank's good performance in controlling the company's earning assets that are still in the first rank, i.e., very good category at $>2$ based on Bank Indonesia criteria.

\subsection{Discussion}

\subsubsection{CAR towards Financial Distress Prediction}

Capital Adequacy Ratio (CAR) is a capital ratio that shows the bank's capacity to provide funds for business development and accommodate the risk of fund losses due to bank operations. CAR represents the extent to which the bank's equity can cover the decline in the bank's assets. The higher the CAR, the better the bank (Achmad, 2003). CAR serves as a ratio of a bank's performance to measure the bank's capital adequacy to support assets that contain or generate risks, such as loans (Dendawijaya, 2005). Following Bank Indonesia provisions, a bank considered a healthy or good bank has a CAR of at least $8 \%$. This is based on the provisions set by BIS (Bank for International Settlements). A study by Almilia and Heriningtyas (2005) suggests that CAR negatively influences the prediction of problematic conditions in the banking sector. Suharman (2007) also opines that the greater the ratio, the lesser the probability of a bank going bankrupt. The following table presents the results of CAR criteria.

Table 10. Results of CAR Criteria

\begin{tabular}{lll}
\hline Year & CAR & Predicate \\
\hline 2016 & $14.74 \%$ & Very Good \\
2017 & $11.35 \%$ & Good \\
2018 & $14.49 \%$ & Very Good \\
2019 & $12.89 \%$ & Very Good \\
2020 & $12.63 \%$ & Very Good \\
\hline Average CAR and Predicate & $\mathbf{1 3 . 8 2} \%$ & Very Good \\
\hline
\end{tabular}

Source: Processed Data, 2020

The above table shows that Bank BRI Unit Wonosari has a very good CAR in 2016, 2018, 2019, 2020 required by Bank Indonesia, which is above $12 \%$. On the other hand, the CAR of the bank is 11.3, with a good predicate in 2017 . On this ground, from 2016 to 2019, Bank BRI Unit Wonosari averagely has a large capital in financing the company's finances to overcome the financial risks that will occur. In terms of maintaining the bank stability so as not to experience financial distress, a bank can anticipate it by keeping credit collectability. Doing such a thing will be impactful on the net interest income of the credit and ensure that the bank has adequate capital to keep the company's financial stability to avoid financial distress.

\subsubsection{NPL Ratio towards Financial Distress}

The analysis results are displayed in the following table: 
Table 11. Predicates of NPL Ratio

\begin{tabular}{lll}
\hline Year & NPL Ratio & Predicate \\
\hline 2016 & 2.98 & Good \\
2017 & 2.76 & Good \\
2018 & 3.05 & Fair \\
2019 & 2.65 & Good \\
2020 & 2.88 & Good \\
\hline Average NPL Ratio and Predicate & $\mathbf{2 . 9 1}$ & Good \\
\hline & Source: Processed Data, 2020
\end{tabular}

The above table gives the fact of the measurement of financial distress based on the NPL Ratio. In 2016, 2017, and 2019, the loans from Bank BRI Unit Wonosari are considered good (2.98 and 2.76\%) under the criteria of Bank Indonesia that range from $2 \%$ to 3\%. Meanwhile, the bad credits in Bank BRI Unit Wonosari in 2018 and 2020 fall under 3.05 and 3.10, meaning that they are in a fair predicate based on the criteria of Bank Indonesia. Therefore, the loans in the aforementioned bank are considered good in giving loans to the customers.

This ratio shows the bank's managerial capacity in managing bad credits; the higher the ratio, the worse the bank's credit quality, leading to greater bad credits and poor bank conditions (Almilia and Heriningtyas, 2005). Giniarto and Ibad (2003) also point out that the higher the NPL, the greater the reserves to be formed and the opportunity cost borne by the bank. Eventually, it can result in potential losses to the bank. A study by Almilia and Heriningtyas (2005) suggests that NPL positively contributes to predicting problematic conditions in the banking sector. NPL reflects credit risks; the lower the NPL, the lesser the credit risks borne by the bank. NPL has a positive effect because if the bank's NPL is high, it will increase the cost of reserves for earning assets or other costs, and potentially causes the bank losses. The higher the ratio, the worse the bank's credit quality, leading to greater bad credits and poor conditions. Regarding this, the research hypothesis is accepted, i.e., the prediction of financial distress in Bank BRI Unit Wonosari is categorized healthy because the bank's NPL ratio is $2.91 \%$ (under 5\%). Based on the criteria of Bank Indonesia, a bank does not experience financial distress if it has an NPL ratio of a maximum of $5 \%$. All in all, the NPL Ratio of Bank BRI Unit Wonosari does not lead the bank to deal with financial distress as its loans fall under a good category.

\subsubsection{NIM Ratio towards Financial Distress}

Provided below are the the NIM Ratio of PT. Bank Rakyat Indonesia (Persero), Tbk Unit Wonosari 2016 - 2020.

Table 12. Predicates of NIM Ratio

\begin{tabular}{lll}
\hline Year & NIM Ratio & Predicate \\
\hline 2016 & 2.15 & Very Good \\
2017 & 2.00 & Good \\
2018 & 2.49 & Very Good \\
2019 & 3.20 & Very Good \\
2020 & 1.99 & Good \\
\hline Average NIM Ratio and Predicate & $\mathbf{2 . 3 6}$ & Very Good \\
\hline \multicolumn{4}{r}{}
\end{tabular}

The above table gives the fact of the measurement of financial distress based on the NIM Ratio. In 2016, 2018, and 2019, the interest income on earning assets from Bank BRI Unit Wonosari is considered very good $(2.15 \%, 2.49 \%$, and $3.20 \%)$ under the criteria of Bank Indonesia that range $>2 \%$. In contrast, the net interest income on earning assets in 2017 and 2020 ranges from 2 to $3 \%$, implying that they are in good health based on the criteria of Bank Indonesia. On the whole, the interest income on earning assets of the bank mentioned above is in a very good category in giving loans to the customers for the performance of the earning assets. To anticipate the possibility of financial distress, the bank can employ a strategy of maintaining the items of interest revenues of incomes, e.g., interest income from customers. If the strategy is carried out by improving collectability, it provides certainty that loan interest income will still be obtained as the purpose of lending.

As defined by Pandia (2012:71), NIM is a ratio used to measure the company's managerial capacity to manage its earning assets to generate net interest income. Many previous studies by Qhairunnissa and Kristanti (2014), Rahmania and Hermanto (2014), Bestari and Rohman (2013) indicate that NIM has a negative and significant effect on financial distress. This also means that the higher the NIM, the lesser it gets for the bank to experience financial distress; the higher the NIM, the better the bank. However, these results are inconsistent with Almilia and Herdiningtyas (2005), stating that NIM negatively and insignificantly affects financial distress.

\section{Conclusion}


The present study aims to determine the effect of Capital Adequacy Ratio (CAR), Non-Performing Loan (NPL), Net Interest Margin (NIM) on the prediction of financial distress of Bank BRI Unit Wonosari from 2016 to 2019. It is concluded from the findings that the CAR, NPL ratio, and NIM ratio towards financial distress in Bank BRI Unit Wonosari in 2016 - 2020 averagely reaches very good health based on the criteria of Bank Indonesia. This implies that the bank does not experience financial distress. This research suggests that the bank maintains its financial stability to avoid financial distress or other financial issues that lead to financial liquidity or bankruptcy. Further studies also should use more independent variables as predictors of problematic conditions, such as the effect of exchange rate volatility, inflation rates, interest rates, and compliance with regulations of bank's health, such as NOP and LLL. This study, however, is only limited to certain variables. Therefore, it is important for further studies to use more variations on independent variables as predictors of problematic conditions, such as the effect of exchange rate volatility, inflation rates, interest rates, and compliance with bank health regulations such as Tax Object Number and Legal Lending Limit.

Funding: This research received no external funding.

Conflicts of Interest: The authors declare no conflict of interest

\section{References}

[1] Achmad, T. (2003). Analisis Rasio-Rasio Keuangan sebagai Indicator dalam Memperbaiki Potensi Kebangkrutan Perbankan di Indonesia [Analysis of Financial Ratios as an Indicator in Improving the Potential for Bankruptcy in Indonesia]. Media Ekonomi dan Bisnis, 15(1), 54-75.

[2] Almalia, L., and Herdiningtyas, W. (2005). Analisis Rasio CAMEL terhadap Prediksi Kondisi Bermasalah pada lembaga perbankan Penerbit Jurnal Akuntansi dan Keuangan [Analysis of CAMEL Ratio towards Prediction of Problematic Conditions in Banking Institutions]. Grasindo

[3] Almilia, L. S. (2004). Analisis Faktor-faktor yang Mempengaruhi Kondisi Financial Distress Suatu Perusahaan yang Terdaftar di Bursa Efek Jakarta [Analysis of Factors Affecting Financial Distress Condition of a Company Listed on the Jakarta Stock Exchange]. Jurnal Riset Akuntansi Indonesia (JRAl), 7(1).

[4] Bestari, A. R., and Rohman, A. (2013). Pengaruh Rasio CAMEL dan Ukuran Bank Terhadap Prediksi Kondisi Bermasalah pada Sektor Perbankan (Studi pada Perusahaan Perbankan yang Terdaftar di Bursa Efek Indonesia). Diponegoro Journal of Accounting, 2(3), 1-9.

[5] Dendawijaya, L. (2005). Manajemen Perbankan [Banking management]. Ghalia Indonesia

[6] Endri, E. (2009). Prediksi Kebangkrutan Bank untuk Menghadapi dan Mengelola Perubahan Lingkungan: Analisis Model Altman Z-Score [Bank Bankruptcy Prediction to Face and Manage Environmental Change: Altman Z-Score Model Analysis]. Jurnal Perbanas Quarterly Review, 2(1), 34-50.

[7] Ganiarto, F. K., and Ibad, A. (2003). Meneropong Kesanggupan Beberapa Bank di DKI Jakarta untuk Memenuhi Ketentuan Rasio NPL Maksimum 5\% pada Juni 2003 [Observing the Ability of Several Banks in DKI Jakarta to Fulfill Requirements for a Maximum NPL Ratio of 5\% in June 2003]. JBII, 10(1).

[8] Qhairunnissa, N.A., and Kristanti, F. T. (2014). Analisis Pengaruh Rasio CAMELS Terhadap Prediksi Kondisi Bermasalah pada Bank Umum yang Terdaftar di Bursa Efek Indonesia periode 2007-2012 [Analysis of the Effect of the CAMELS Ratio on the Prediction of Troubled Conditions in Commercial Banks Listed on the Indonesia Stock Exchange for the period 2007-2012]. EJournal Telkom University, 1(3).

[9] Rahmania, M. F., and Hermanto, S. B. (2014). Analisis Rasio Keuangan Terhadap Financial Distress Perusahaan Perbankan Studi Empiris di BEl 2010-2012 [Analysis of Financial Ratios on Financial Distress of Banking Companies Empirical Study on IDX 2010-2012]. Jurnal Ilmu \& Riset Akuntansi, 3(1), 1-20.

[10] Riyadi, S. (2006). Banking Assets and Liability Management. PT. Raja Grafindo Persada.

[11] Suharman, H. (2007). Analisis Risiko Keuangan untuk Memprediksi Tingkat Kegagalan Usaha Bank [Financial Risk Analysis to Predict Bank Business Failure Rate]. Jurnal Imiah ASET, 9(1).

[12] Usman, B. (2003). Analisis Rasio Keuangan dalam Memprediksi Perubahan Laba pada Bank-Bank di Indonesia [Financial Ratio Analysis in Predicting Changes in Profit at Banks in Indonesia], Media Riset Bisnis \& Manajemen, 3(1).

[13] Winarto, J. (2006). Prediksi Kinerja Keuangan Perusahaan Dengan Pendekatan Bankruptcy Model Altman's Z-Score [Predicting the Company's Financial Performance with the Bankruptcy Approach Altman's Z-Score Model]. MODUS, 18(1), 1-9. 